\title{
Smart Factory. What Employees Will the Company Need in the Future?
}

\section{Smart Factory. Jaké zaměstnance bude firma potřebovat $v$ budoucnu?}

Aleš Gregarl, Ivana Pejřovál, Jana Matoškovál

${ }^{1}$ Univerzita Tomáše Bati ve Zlíně, Zlín, Česká republika

\begin{abstract}
Objective. The purpose of the paper is to provide information about a research project aimed at supporting the implementation of the Smart Factory concept (management system with support of digitization and robotization) in the production plant ALPS Electric CZ, Sebranice, regarding changes in working roles, working conditions, development of employees, changes in conditions for in-company communication and overall changes in corporate culture in ALPS Electric CZ, Sebranice. For research purposes, the research problem was formulated and six research questions were set.
\end{abstract}

Method. About 400 employees work at ALPS, of which about 350 are in production. The research target groups are six work groups that are directly related to production - process engineers, foremen, purchasing, planning and production preparation, logistics (focusing on material supply), manufacturing operators and middle management. Methods for data collection: document analysis, interviews, questionnaire, and findings from selected companies. With regard to the realization of research in one company, we will use descriptive statistics for the analysis and interpretation of data.

Conclusion. The findings of the research will help ALPS management to identify and eliminate potential barriers concerning employees when implementing the Smart Factory concept. We will propose measures to support the implementation of the Smart Factory concept in the ALPS specifically focused on work positions and system measures supporting the "smart" change of the ALPS Electric corporate culture.

Limitations. The conclusions of the research are based on one medium-sized production plant, and are not generally valid. The Smart Factory concept focuses only on the range of jobs that are directly related to production; it does not take into account the need to assess the impact of digitizing jobs indirectly related to production (ECO, HR, MKT).

Keywords. Smart Factory; management system; digitization, robotization; work position; qualifications, working conditions; organizational culture

https://doi.org/10.5817/CZ.MUNI.P210-9488-2019-11 


\begin{abstract}
Abstrakt
Cíl. Účelem príspěvku je podat informaci o výzkumném projektu, jehož cílem je podpora implementace konceptu Smart Factory (systém řizeni s podporou digitalizace a robotizace) $v$ prostředí výrobního závodu ALPS Electric CZ, Sebranice, s ohledem na změny pracovních rolí, pracovních podminek, kvalifikačních požadavků, kariérových modelů rozvoje pracovniků, změny podmínek pro vnitrofiremni komunikaci a celkové změny firemni kultury v ALPS Electric CZ, Sebranice. Pro účely výzkumu byl formulován výzkumný problém a stanoveno šest výzkumných otázek.
\end{abstract}

Metoda. V ALPS pracuje cca 400 pracovníků, z toho cca 350 operátorů ve výrobě. Cílovou skupinou výzkumu je sedm okruhů pracovních mist, která mají př́mý vztah k výrobè-procesní inženýri, předáci a mistři, nákup, plánováni a př́prava výroby, logistika (se zaměřením na zásobování výroby materiálem), operátoři ve výrobě a střední management. Metody pro sběr dat: analýza dokumentů, rozhovory, dotaznik, poznatky z vybraných firem. S ohledem na realizaci výzkumu v podmínkách jedné firmy použijeme pro analýzu a interpretaci dat popisnou statistiku.

Závěry. Závěry výzkumu pomohou vedeni ALPS identifikovat a eliminovat možné bariéry na straně pracovníků př implementaci konceptu Smart Factory. Navrhneme opatření na podporu implementace konceptu Smart Factory v prostředi ALPS specificky zaměrené na jednotlivé okruhy pracovnich pozic a systémová opatrení podporujicí „smart“ změnu firemní kultury ALPS Electric CZ.

Limity. Závěry výzkumu vycházejí z podmínek jednoho výrobního závodu střední velikosti, nemaji obecnou platnost. Koncept Smart Factory je zaměren jen na okruh pracovních mist, které maji př́mý vztah $k$ výrobě, není brána do úvahy potřeba vyhodnocovat vliv digitalizace pracovnich mist neprimo souvisejicich s výrobou (EKO, HR, MKT).

Klíčová slova. Smart Factory; systém řízení; digitalizace, robotizace; pracovní pozice; kvalifikace, pracovní podmínky; organizační kultura

\title{
Úvod
}

Chytrá továrna (smart factory, SF) je systém řízení s podporou robotizace, digitalizace, big data, Industrial Internet of Things (IIoT) a umělé inteligence (Artificial Intelligence, AI). Koncept SF představuje skok vpřed od tradiční automatizace k plně připojenému a flexibilnímu systému, který může používat nepřetržitý tok dat z připojených operací a výrobních systémů, aby se učil a přizpůsobil se novým požadavkům. I v inteligentní továrně se ale předpokládá, že lidé stále budou klíčem k operacím a procesům. Dojde však k velkým změnám v charakteristice požadovaných operací a tím ke změně rolí na podporu nových procesů, ke změně požadavků na znalosti, dovednosti a schopnosti pracovníků. Část rolí bude postupně zanikat, protože je budou nahrazovat kolaborativní roboti a automatizace procesů. Další role budou doplněny o nové funkce např́klad o virtuální realitu, vizualizaci dat a umělou inteligenci. Objeví se také role nové, zatím neznámé (Balga, 2018; Frey \& Osborne, 2013). 
Nové technologie odstraní fyzicky namáhavé a rutinní práce, práce, které jsou životu nebezpečné, či jejichž dlouhodobý výkon ohrožuje zdraví a způsobuje nemoci z povolání. Přinesou také možnost kvalitativního obohacení práce, jejího výkonu $\mathrm{v}$ zajímavějším pracovním prostředí, větší autonomii a více příležitostí pro profesní rozvoj a prostor pro inovativní myšlení. Na druhé straně, nové výrobní postupy kladou jiné požadavky na pracovní způsobilost pracovníků (Kolektiv NVF-NOZV, 2017; Ras et al., 2017; Chmelař et al., 2015).

Proces digitalizace ekonomiky neznamená jen ohrožení určitých profesí a pracovních míst, popř. jejich významnou transformaci, ale vytváří také předpoklady pro vznik profesí a pracovních míst zcela nových. Největší potenciál vzniku pracovních míst je spojován $\mathrm{s}$ rozvojem ICT a zaváděním nových technologií, s budováním platformy Průmyslu 4.0 a obecně Společnosti 4.0. Vzhledem k tomu, že firma ALPS je napojena na automobilový průmysl, musí věnovat velkou pozornost postupu digitalizace, robotizace a rozvoji ICT. Charakteristiky SF v automobilové výrobě směrují k trvalému zvyšování výkonosti, orientaci na zákazníky, individualizaci výroby, zlepšování pracovních podmínek ve výrobním procesu, snižování pracovní zátěže uplatněním ergonomických opatření a k zodpovědnému vztahu k životnímu prostředí (Kohout \& Palíšková, 2017; Yuan et al., 2017).

Pravděpodobně vzroste počet pracovních míst vyžadujících vyšší úroveň vzdělání. Požadavek na úzkou specializaci $v$ jednom oboru ustoupí a budou vyžadovány současně hluboké odborné znalosti v jednom oboru a široké znalosti napříč mnoha disciplínami. Budoucí zaměstnanec by měl tedy disponovat komplexnějšími znalostmi a dovednostmi, aby byl schopen uvažovat a rozhodovat se v širších souvislostech (Jackson et al., 2003; Davenport \& Prusak, 1998).

Zaměstnanci budou muset rozumět procesům, jejich vzájemné provázanosti a budou potřebovat znalosti a dovednosti spojené se sběrem a použitím dat (Ras et al., 2017). Proto by součástí základního vzdělání každého jedince měla být digitální gramotnost, zejména schopnost umět informační a komunikační technologie používat $\mathrm{k}$ efektivnímu řešení problémů a schopnost efektivně pracovat s informacemi. Kromě hard-skills (odborných, technických a jazykových dovedností) bude dále narůstat význam soft-skills (Kohout \& Palíšková, 2017; Horváthová et al., 2016; Frey \& Osborne, 2013).

Důležitá bude schopnost komunikace, koncepčního a kritického myšlení, sociální inteligence, kreativita, schopnost vedení týmu a spolupráce, odolnost vůči stresu, schopnost rychle reagovat a samostatně se rozhodovat a řešit problémy, schopnost sdílet informace, schopnost tolerance a sebeřízení (Kolektiv NVF-NOZV, 2017; Amidi et al., 2017).

Zároveň budou kladeny větší nároky na flexibilitu pracovníků. Bude vyžadována rychlá reakce $\mathrm{v}$ odpovědi na změny potřeb různých zákazníků i profesní flexibilita ze strany pracovníků, jejich neustálé vzdělávání a výchova příslušných specialistů, které si každý podnik bude doplňovat vzdělání podle svých potřeb. S tím souvisí narůstající význam celoživotního vzdělávání, např́iklad schopnost průběžně si osvojovat nové trendy v technologiích a neustále rozvíjet své IT znalosti a dovednosti a potřebnost proaktivního př́stupu a samostatnosti zaměstnanců. Zaměstnanci budou muset akceptovat změnu jako přirozenou součást života (Kohout \& Palíšková, 2017; Ras et al., 2017; Yuan et al., 2017). 
V souvislosti s postupující ekonomickou globalizací a internacionalizací lze očekávat, že zaměstnanci budou stále častěji pracovat v prostředí multikulturních týmů. To bude vyžadovat interkulturní senzitivitu, tj. disponovat určitými interkulturními kompetencemi, do kterých se promítají osobnostní předpoklady jako sebereflexe, empatie, kulturní citlivost, zvídavost, zkušenost, tolerování odlišnosti a sebedůvěra či snížená míra úzkostlivosti. Pracovníci v multikulturním týmu by měli umět respektovat druhé, mít znalosti o jiných kulturách a neříkat si, že vše umí nejlépe a netrvat na tom, že věci se musí dělat bezpodmínečně jen jejich osvědčeným způsobem. Je zapotřebí, aby se lidé naučili respektovat jiný způsob myšlení kolegů, jejich odlišný styl práce, př́istup k lidem, konfliktům a jejich odlišné nastavení priorit v pracovním i osobním životě (Šlapalová Čempelová, 2013; Yuan et al., 2017; Frey \& Osborne, 2013).

Výzkumný problém vyplývající z teoretického úvodu lze formulovat následovně:

Jaký vliv má digitalizace řízení výroby a implementace konceptu SF na zaměstnance? Jak podporovat implementaci konceptu SF s ohledem na úspěšné zvládnutí změny pracovních rolí, změny pracovních podmínek, změny kvalifikačních požadavků, změny karierových modelů rozvoje pracovníků, změny motivačních faktorů, změny podmínek pro vnitrofiremní komunikaci a celkové změny podnikové kultury v ALPS?

Výzkumné otázky vyplývající z teoretického úvodu lze stanovit následovně.

VO1: Které okruhy pracovních pozic jsou relevantní pro systém ř́zení SF v prostředí ALPS?

VO2: Které specifické povinnosti, potřeby a požadavky pro jednotlivé okruhy pracovních pozic jsou relevantních pro systém řízení SF v ALPS?

VO3: Které Key Performace Indicators (KPI) pro jednotlivé okruhy pracovních pozic jsou relevantní pro systém řízení SF v ALPS?

VO4: Které překážky v jednotlivých okruzích pracovních pozic jsou relevantní pro implementaci systému ř́izení SF? Jaká jsou opatření pro jejich překonání?

VO5: Jaký je vliv systému řízení SF na stávající firemní kulturu ALPS (hodnoty, normy chování, artefakty)?

VO6: Jaká jsou opatření pro formování „smart“ firemní kultury pro ALPS jako podpora systému řízení SF v prostředí ALPS?

\section{Metody}

Pro zodpovězení VO1 bude provedena analýza současného stavu, tj. přehled pracovních míst, popisy pracovních míst, roztřídění pracovních míst podle relevance ve vztahu $\mathrm{k}$ implementaci systému řízení SF v podmínkách ALPS. Pro třídění pracovních míst bude použita tříbodová škála: „,ano, možná, ne“, s ohledem na to, do jaké míry budou jednotlivá pracovní místa ovlivněna implementací $\mathrm{SF}$, přičemž ano $=2$ body, možná $=1$ body, ne $=0$ bod. Toto hodnocení provedou individuálně členové pracovního týmu (10 osob).

Pro zodpovězení VO2 bude využita Národní soustavu povolání, a následně budou vytipovány, které specifické povinnosti, potřeby, požadavky, odborné a obecné znalosti a dovednosti u zaměstnanců může přechod ke SF ovlivňovat. 
Pro zodpovězení VO3 bude provedena analýza současného stavu KPI pro jednotlivé okruhy pracovních pozic relevantních pro systém řízení SF v ALPS a budou navržena opatření pro jejich úpravu.

Pro zodpovězení VO4 bude provedena analýza současného stavu existence překážek v jednotlivých okruzích pracovních pozic relevantních pro implementaci systému řízení SF a budou navržena opatření pro jejich překonání.

Pro zodpovězení VO5 a VO6 bude provedena analýza vlivu systému řízení SF na stávající firemní kulturu ALPS (hodnoty, normy chování, artefakty) a budou navržena opatření pro formování „smart“ firemní kultury pro ALPS jako podpory systému rrízení SF v prostředí ALPS.

Pro zodpovězení otázek VO1 až VO6 budou využity také poznatky z vybraného okruhu firem, které se tématem digitalizace řízení výroby a konceptem SF zabývají (publikace, konference, semináře, workshopy).

Pro zodpovězení otázek VO3 až VO6 budou využity řízené rozhovory, včetně formuláře pro záznam odpovědí. Otázky pro řízené rozhovory budou stanoveny na základě současného stavu dané problematiky $\mathrm{v}$ ALPS a na základě poznatků $\mathrm{z}$ literatury $\mathrm{k}$ danému tématu. Předpokládáme, že rozhovory s pracovníky ALPS proběhnou v řrijnu/listopadu 2019, cca 20 rozhovorů, délka 30-45 minut.

Pro zodpovězení otázek VO5 a VO6 bude využita metoda dotazníku. Dotazník bude vybrán z okruhu dotazníků používaných při výzkumu firemní kultury (Bock et al., 2005; Yang, 2007). Dotazníkové šetření proběhne na jaře 2020, cca. 100 respondentů.

Firma ALPS má cca 400 pracovníků, z toho cca 350 na pozicích operátorů ve výrobě a na montáži. Respondenty budou pracovníci z těchto sedmi okruhů pracovních míst: procesní inženýři, předáci a mistři, nákup, plánování a př́prava výroby, logistika (se zaměřením na zásobování výroby materiálem), operátoři ve výrobě a stř̌ední management. Těchto sedm okruhů pracovních míst bylo stanoveno po konzultaci s personálním oddělením firmy ALPS. Kritériem pro tento výběr byl přímý vztah těchto pracovních pozic $\mathrm{k}$ výrobnímu úseku.

$\mathrm{S}$ ohledem na realizaci výzkumu v podmínkách jedné firmy (ALPS) bude pro analýzu a interpretaci dat použita popisná statistika.

\section{Závěr}

Výsledkem řešení projektu budou opatření na podporu implementace konceptu SF s ohledem na úspěšné zvládnutí změny pracovních rolí, změny pracovních podmínek, změny kvalifikačních požadavků, změny karierových modelů rozvoje pracovníků, změny motivačních faktorů, změny podmínek pro vnitrofiremní komunikaci a celkové změny podnikové kultury ve firmě ALPS. K formulaci opatření budou využity poznatky z odborných publikací, informace zjištěné pomocí rozhovorů ve vybraných firmách (best practices), výsledky výzkumu realizovaného ve firmě ALPS Electric CZ Sebranice.

V podmínkách firmy ALPS byly definovány tyto oblasti výzkumu:

- stanovení okruhů pracovních pozic relevantních pro implementaci konceptu SF v prostředí ALPS, 
- stanovení specifických povinností, potřeb a požadavků pro jednotlivé okruhy pracovních pozic relevantních pro SF v ALPS,

- stanovení KPI pro jednotlivé okruhy pracovních pozic relevantních pro SF $\mathrm{v}$ ALPS,

- identifikace potenciálních implementačních překážek v jednotlivých okruzích pracovních pozic relevantních pro SF a stanovení možných opatření k jejich překonání,

- identifikace vlivu SF na stávající firemní kulturu ALPS (hodnoty, normy chování, artefakty),

- stanovení opatření pro formování „smart“ firemní kultury pro ALPS jako podpora implementace SF v prostředí ALPS.

V současnosti je velmi obtížné přesně určit, jak se budou jednotlivé pracovní pozice měnit, popř. zanikat či vznikat zcela nové, jaké konkrétní znalosti a dovednosti budou s nimi spojeny, lze identifikovat jen určité obecné trendy. To, jaké dopady bude mít zavádění technologií na zaměstnance, zda zaměstnanci budou technologie vnímat jako užitečné nebo ohrožující, bude mimo jiné ovlivněno firemní kulturou dané organizace. S jistotou však lze říci, že získané znalosti a dovednosti budou zastarávat mnohem rychleji, než je tomu nyní. $Z$ tohoto důvodu vzroste význam celoživotního vzdělávání, včetně podnikových forem vzdělávání (Kohout \& Palíšková, 2017).

Je zřejmé, že kromě posunu ve formách zaměstnávání budou v důsledku digitalizace a robotizace probíhat na pracovištích minimálně dvě další zásadní změny. Zaprvé, bude ve zvýšené míře docházet k zániku a vzniku pracovních míst a profesí, popřr. k jejich transformaci. Zadruhé, významně vzrostou nároky na kvalifikaci pracovníků resp. její změnu (na všech úrovních), proto oblast personálního řízení ve firmách musí projít změnou od tradiční orientace na administrativu spojenou s pracovní sílou, k podpoře rozvoje a angažovanosti pracovníků. Poroste význam podnikového vzdělávání, a to i u starších zaměstnanců či u operátorů. I operátoři budou muset rozumět datům a umět si pro jejich práci potřebná data zobrazit, analyzovat a interpretovat je. Bude zapotřebí pracovníky průběžně přšškolovat a rekvalifikovat na nové technologie.

$\mathrm{V}$ souvislosti s různými generacemi zaměstnanců (generace $\mathrm{X}, \mathrm{Y}$ a Z ), které se ve firmě potkávají, jejich odlišnostem v př́stupu k práci, IT schopnostem a dovednostem, je potřebné přijmout koncept Age managementu, který pracuje s přednostmi všech věkových kategorií zaměstnanců. Důležité bude podporovat angažovanost zaměstnanců a jejich zapojení do chodu firmy. Ke klíčovým motivátorům pro pracovníky bude patřit, osobní růst (př́iležitost pro jedince plně realizovat svůj potenciál), autonomie, uspokojení z práce vysoké kvality, významné pro firmu. Dále, otevřené vztahy na pracovišti, kvalitní komunikace, soulad s posláním organizace, sdílené firemní hodnoty, silná firemní kultura.

Výzkum řeší digitalizaci a robotizaci jako podporu pro ř́zení výroby, není řešena transformace řízení dalších úseků (EKO, HR, MKT). Koncept SF musí řešit transformaci celé firmy v souvislosti s digitalizací a robotizací. Tento požadavek je zadáním pro další pokračování výzkumu v oblasti SF v ALPS. 


\section{Literatura}

Amidi, A., M., Jabar, Y. Y., \& Abdullah, R. (2017). Appropriation of social media for fostering effective tacit knowledge sharing: developing conceptual model. Journal of Physics: Conference Series, 892(1), 1-2012. http://doi.org/10.1088/1742$\underline{6596 / 892 / 1 / 012012}$

Balga, B. (2018). SMART factory - inteligentní továrna - IPA Czech. Dostupné z: https://www.ipaczech.cz/cz/tisk-a-media/aktuality/smart-factory-inteligentni-tovarna

Bock, G., Zmud, R. W., Kim, Y., \& Lee J. (2005). Behavioral intention formation in knowledge sharing: Examining the roles of extrinsic motivators, social-psychological forces, and organizational climate. MIS quarterly, 29(1), 87-111. https://doi.org/10.2307/25148669

Davenport, T. H., \& Prusak, L. (1998). Working knowledge: how organizations manage what they know. Boston, Mass: Harvard Business School Press.

Horváthová, P., Bláha, J. \& Čopíková, A. (2016). Řizení lidských zdrojů: Nové trendy. B.m.: Management Press.

Frey, C. B. \& Osborne, M. A. (2013). The Future of Employment: How susceptible are jobs to computerisation? Oxford University, September 17, 2013. (cit. 2019-04-28). Dostupné z: https://grid.cs.gsu.edu/ nkeller4/The\%20Future\%20of\%20Employment.pdf

Chmelar̆, A. et al. (2015). Dopady digitalizace na trh práce v ČR a EU. OSTEU Discussion paper, 12. Dostupné z: https://www.vlada.cz/assets/evropskezalezitosti/analyzyEU/Dopady-digitalizace-na-trh-prace-CR-a-EU.pdf.

Jackson, S. E., Hitt, M. A. \& Denisi, A. S. ed. (2003). Managing knowledge for sustained competitive advantage: designing strategies for effective human resource management. San Francisco: Jossey-Bass. The organizational frontiers series.

Kohout, P. \& Palíšková, M. (2017). Dopady digitalizace na zaměstnanost a sociální zabezpečení zaměstnanců [online]. červenec 2017. Dostupné z: http://ipodpora.odbory.info/soubory/dms/wysiwyg_uploads/bba5a5c7366cdaf3/uploads/St udie_Dopady_digitalizace.docx

Kolektiv NVF-NOZV. (2017). Dopady Průmyslu 4.0 na trh práce v $\check{C} R$ [online]. 2017. B.m.: Národní vzdělávací fond. Dostupné z:

http://www.nvf.cz/cms/assets/docs/88ffb3e9f7da58fefd9741bca08796a3/794-0/dopadyprumyslu4.0-na-trh-prace-v-cr.pdf

Ras, E., Wild, F., Stahl, Ch. et al. (2017). Bridging the Skills Gap of Workers in Industry 4.0 by Human Performance Augmentation Tools: Challenges and Roadmap. In: The 10th International Conference: Proceedings of the 10th International Conference on Pervasive Technologies Related to Assistive Environments - PETRA '17 [online] (pp. 428-432). Island of Rhodes, Greece: ACM Press. http://doi.org/10.1145/3056540.3076192

Šlapalová Čepelová, Z. (2013). Cesta k multikulturnímu týmu [online]. Dostupné z: http://modernirizeni.ihned.cz/c1-60518520-cesta-k-multikulturnimu-tymu 
Yang, J. (2007). Knowledge sharing: Investigating appropriate leadership roles and collaborative culture. Tourism Management, 28(2), 530-543.

http://doi.org/10.1016/j.tourman.2006.08.006

Yuan, Y. H., Tsai, S. B., Dai, C.Y., et al. (2017). An empirical research on relationships between subjective judgement, technology acceptance tendency and knowledge transfer. PLoS ONE, 12(9). http://doi.org./10.1371/journal.pone.0183994

\section{Korespondující autor}

doc. PhDr. Ing. Aleš Gregar, CSc.

Univerzita Tomáše Bati ve Zlíně, Fakulta managementu a ekonomiky

Mostní 5139, 76001 Zlín, Česká republika

gregar@utb.cz

Grantová podpora: Výzkumný projekt je podporován grantem MPO ČR, OPPIK - program APLIKACE - Výzva č. IV, termín řešení 3/2019 - 8/2020. 